- Case Report

\title{
A Possible Case of Statin-Induced Ichthyosis in an Elderly Woman
}

\author{
Ki Dong Ko', Kyoung Kon Kim ${ }^{1 *}$, Jin-Ok Baek², Heuy Sun Suh', In Cheol Hwang ${ }^{1}$ \\ 'Department of Family Medicine, Gachon University Gil Medical Center, Incheon, Korea \\ ${ }^{2}$ Department of Dermatology, Gachon University Gil Medical Center, Incheon, Korea
}

Ichthyosis is a heterogeneous group of hereditary or acquired skin disorders, characterized by increased stratum corneum production. Several systemic diseases and many drugs can occasionally cause acquired ichthyosis. We report a case of statin-induced ichthyosis in which the causality between statin and ichthyosis was found possible by using the Naranjo scale. A 79-year-old woman presented with pruritic skin lesions on both legs that appeared erythematous, scaly, and cracked. A clinical diagnosis of acquired ichthyosis was made and the statin was suspected as the cause. The skin lesions improved after 6 weeks of dose reduction of the statin.

Keywords: Hydroxymethylglutaryl-CoA Reductase Inhibitors; Statin; Ichthyosis; Skin 


\section{INTRODUCTION}

Ichthyosis is a heterogeneous group of hereditary or acquired scaly skin disorders, characterized by increased stratum corneum production. Acquired ichthyosis is rare and usually occurs in the elderly in association with several systemic diseases (e.g., solid or blood cancers, infectious diseases, endocrinopathies, autoimmune diseases, nutritional deficiency). ${ }^{1)}$ Many drugs may also cause this skin disease and these drugs include allopurinol, cimetidine, and some types of antipsychotics and lipid-lowering drugs. ${ }^{1)}$ Hydroxymethylglutaryl-CoA reductase inhibitors, namely statins, are the most widely used class of lipid-lowering drugs. Here, we report a rare possible case of statin-induced ichthyosis.

\section{CASE REPORT}

A 79-year-old woman presented with a 2-week history of pruritic skin lesions on both legs. The lesions appeared erythematous, scaly, and cracked and were more prominent on the extensor surfaces of her legs (Figure 1A). According to her medical history, she had hypertension and was taking medications (perindopril $4 \mathrm{mg}$ and torasemide $2.5 \mathrm{mg}$ ) without changing the prescription for 5 years. Moreover, she started taking pitavastatin $2 \mathrm{mg}$ once daily for dyslipidemia 3 months ago. She had no personal or family history of ichthyosis. She denied smoking or drinking. Her vital signs were within normal ranges. On physical examination, there were no bilateral lung crackles, hepatomegaly, splenomegaly, or lymphadenopathy. Total cholesterol and triglyceride were $115 \mathrm{mg} / \mathrm{dL}$ and $125 \mathrm{mg} / \mathrm{dL}$, respectively, which were relatively low lipid levels. Other hematological and biochemical blood tests were in normal ranges. A chest X-ray showed no active lung lesion.

A clinical diagnosis of acquired ichthyosis was made by a dermatologist. The statin was suspected as the cause. However, she did not want to stop the drug. As an alternative, the dose was reduced by half (pitavastatin $1 \mathrm{mg}$ ). Moreover, the dermatologist started topical treatment with urea cream and tretinoin cream. No skin biopsy was per- formed, because of her reluctance and significant improvement in the skin lesions after 6 weeks of statin dose reduction (Figure 1B). Over a period of a few months, she had a complete remission of the skin lesions.

We assessed the causality between statin and ichthyosis by using the Naranjo adverse drug reaction probability scale. ${ }^{2)}$ Taking all relevant data into account, a possible relationship was found with a score of 3 (with the answers for this case underlined in Table 1).

\section{DISCUSSION}

To the best of our knowledge, this is the first report of statin-induced ichthyosis in Asia. A few case reports have described acquired ichthyoses related to lipid-lowering drugs. ${ }^{3,4)}$ Sparsa et al. ${ }^{3)}$ reported a 52-year-

Table 1. Naranjo ADR probability scale: items and score

\begin{tabular}{|c|c|c|c|}
\hline Question & Yes & No & $\begin{array}{l}\text { Do not know } \\
\text { or not done }\end{array}$ \\
\hline Are there previous conclusive reports on this reaction? & +1 & $\underline{0}$ & 0 \\
\hline $\begin{array}{l}\text { Did the adverse event appear after the suspect drug } \\
\text { was administered? }\end{array}$ & +2 & -1 & 0 \\
\hline $\begin{array}{l}\text { Did the ADR improve when the drug was discontinued } \\
\text { or a specific antagonist was administered? }\end{array}$ & +1 & 0 & $\underline{0}$ \\
\hline $\begin{array}{l}\text { Did the ADR reappear when the drug was re-adminis- } \\
\text { tered? }\end{array}$ & +2 & -1 & $\underline{0}$ \\
\hline $\begin{array}{l}\text { Are there alternate causes (other than the drug) that } \\
\text { could solely have caused the reaction? }\end{array}$ & -1 & +2 & $\underline{0}$ \\
\hline Did the reaction reappear when a placebo was given? & -1 & +1 & $\underline{0}$ \\
\hline $\begin{array}{l}\text { Was the drug detected in the blood (or other fluids) in a } \\
\text { concentration known to be toxic? }\end{array}$ & +1 & 0 & $\underline{0}$ \\
\hline $\begin{array}{l}\text { Was the reaction more severe when the dose was inc- } \\
\text { reased or less severe when the dose was decreased? }\end{array}$ & +1 & 0 & 0 \\
\hline $\begin{array}{l}\text { Did the patient have a similar reaction to the same or } \\
\text { similar drugs in any previous exposure? }\end{array}$ & +1 & 0 & $\underline{0}$ \\
\hline Was the adverse event confirmed by objective evidence? & +1 & $\underline{0}$ & 0 \\
\hline
\end{tabular}

Answers for this case are underlined. Scoring for Naranjo algorithm: $\geq 9$, definite ADR; 5-8, probable ADR; 1-4, possible ADR; 0, doubtful ADR.

$A D R$, adverse drug reaction.
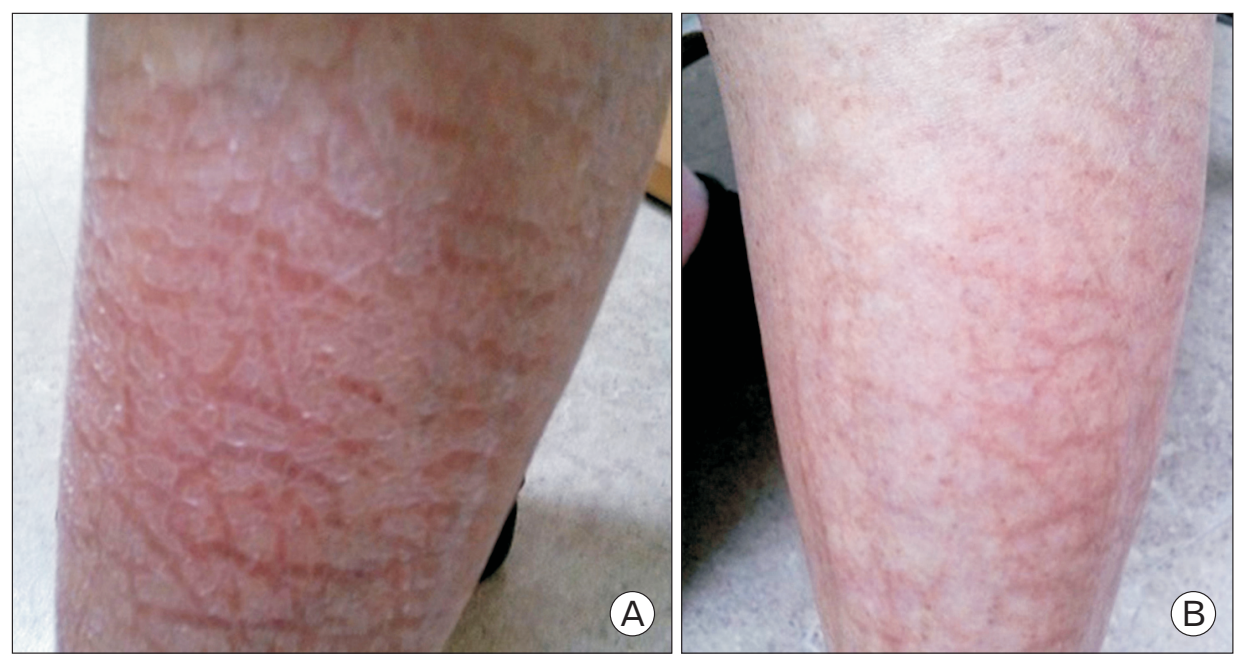

Figure 1. (A) After 3 months of treatment with pitavastatin, she presented with localized acquired ichthyosis on both legs that appeared erythematous, scaly, and cracked. (B) The skin lesions improved after 6 weeks of dose reduction of pitavastatin. 
old woman with localized acquired ichthyosis on her arms after treatment for 2 months with pravastatin. Lacour et al. ${ }^{4}$ also reported a case of acquired ichthyosis during fenofibrate treatment. Authors of these case reports proposed that prolonged lipid-lowering therapy could lower skin cholesterol concentrations, worsen the barrier and desquamation functions in the epidermis, and thus cause acquired ichthyosis.

In contrast, a previous randomized trial found that an effect of statins on epidermal cholesterol concentrations was unlikely.5) A recent systematic review also demonstrated that skin cholesterol and serum cholesterol concentrations were not correlated. ${ }^{6)}$ Therefore, an asyet-unidentified disruption of lipid composition, not the diminution of cholesterol levels in the epidermis, could be responsible for the loss of epidermal functions and acquired ichthyosis. In conclusion, pathophysiological mechanisms explaining statin-induced ichthyosis are far from clear and it is uncertain whether ichthyosis is a class effect of statins or is specific to individual statins. Further research is needed.

Common side effects of statins are dyspepsia, muscle or joint pain, elevation of liver transaminase, and a slightly increased risk of diabetes. ${ }^{7)}$ Statin-induced skin manifestations are infrequent but include ichthyosis, cheilitis, autoimmune reactions, drug reaction with eosinophilia and systemic symptoms, acute generalized pustulosis, phototoxicity, alopecia, and contact dermatitis. ${ }^{8)}$ Recently, it has been reported that statins may increase the likelihood of developing zoster. ${ }^{9)}$ Concerns about adverse reactions may be appropriate in Asians who have higher plasma levels at the same doses and heightened responses to the same plasma levels of statins compared with Caucasians. ${ }^{10)}$

\section{CONFLICT OF INTEREST}

No potential conflict of interest relevant to this article was reported.

\section{REFERENCES}

1. DiGiovanna JJ, Robinson-Bostom L. Ichthyosis: etiology, diagnosis, and management. Am J Clin Dermatol 2003;4:81-95.

2. Naranjo CA, Busto U, Sellers EM, Sandor P, Ruiz I, Roberts EA, et al. A method for estimating the probability of adverse drug reactions. Clin Pharmacol Ther 1981;30:239-45.

3. Sparsa A, Boulinguez S, Le Brun V, Roux C, Bonnetblanc JM, Bedane C. Acquired ichthyosis with pravastatin. J Eur Acad Dermatol Venereol 2007;21:549-50.

4. Lacour JP, Adrien A, Ortonne JP. Acquired ichthyosis during lipid-normalizing treatment. Presse Med 1986;15:668.

5. Reiter M, Wirth S, Pourazim A, Baghestanian M, Minar E, Bucek RA. Statin therapy has no significant effect on skin tissue cholesterol: results from a prospective randomized trial. Clin Chem 2005;51:252-4.

6. Tashakkor AY, Mancini GB. The relationship between skin cholesterol testing and parameters of cardiovascular risk: a systematic review. Can J Cardiol 2013;29:1477-87.

7. Macedo AF, Taylor FC, Casas JP, Adler A, Prieto-Merino D, Ebrahim S. Unintended effects of statins from observational studies in the general population: systematic review and meta-analysis. BMC Med 2014;12:51.

8. Jowkar F, Namazi MR. Statins in dermatology. Int J Dermatol 2010;49: 1235-43.

9. Antoniou T, Zheng H, Singh S, Juurlink DN, Mamdani MM, Gomes T. Statins and the risk of herpes zoster: a population-based cohort study. Clin Infect Dis 2014;58:350-6.

10. Cho YG, Song HJ, Park BJ; NECA-9 Lipid Lowering Agents Research Group. The comparison of guidelines for management of dyslipidemia and the appropriateness of them in Korea. Korean J Fam Med 2010;31:171-81. 